\title{
INCIDENCE AND PREVALENCE OF PARASITES IN EXOTIC SUIS-LARGE WHITE (SUIDAE) SLAUGHTERED IN A TROPICAL URBAN ABATTOIR
}

\author{
EYO J.E. ${ }^{*}$, ECHI P.C. ${ }^{1}$, ATAMA C.I. ${ }^{1}$, ONYISHI G.C. ${ }^{1}$, EKEH F.N. ${ }^{1}$, IVOKE N. ${ }^{1}$, NWANI C.D. ${ }^{1}$, OBITTE B.C. ${ }^{1}$ AND \\ ONOJA U.S. ${ }^{2}$
}

1Department of Zoology and Environmental Biology, University of Nigeria, Nsukka, Enugu State, Nigeria. 2Department of Home Science, Nutrition and Dietetics, Faculty of Agriculture, University of Nigeria, Nsukka, Enugu State, Nigeria. ${ }^{*}$ Corresponding Author: Email- joseph.eyo@unn.edu.ng

Received: October 02, 2013; Accepted: January 06, 2014

\begin{abstract}
Parasitic investigation was carried out to determine the incidence and prevalence of the parasites of exotic Suis (large white) slaughtered for meat in Nsukka, Nigeria. All the 180 large white examined were infected with either or both ecto- and endoparasites. The ectoparasites were Sarcoptes suis and Haematopinus suis and endoparasites were Strongyloides ransomi, Eimeria sp and Ascaris suum. Among the endoparasites, Eimeria sp. had the highest prevalence (51.70\%), followed by S. ransomi (41.10 \%) and A. suum (31.10\%). S. suis $(35.50 \%)$ was more prevalent than $H$. suis $(6.60 \%)$. Incidence of the endoparasites was high being $142.60 \%$ of S. ransomi, $1350 \%$ of Eimeria sp. and $104.30 \%$ of $A$. suum. Incidence of $S$. suis was $146.40 \%$ and that of $H$. suis was $38.7 \%$. The prevalence of haemoparasites encountered during the survey were Trypanosoma brucei (10.00\%) T. congolense, (13.30\%) Babesia trautmanni (42.77\%) and Babesia perroncitoi $(33.89 \%)$ and the incidences of these parasites were $31.40,45.00,127.79$ and $95.78 \%$, respectively. Age groups $7-9$ months were mostly affected by various ectoparasites except in the infection of $H$. suis which was recorded mostly in the young stock 4-6 months of age. Age groups 7-9 months were mostly affected by haemoparasites followed by above 9 months and lastly 4-6 months old pigs.
\end{abstract}

Keywords- Pig, Suis, Parasites, Haemoparasites, Prevalence, Incidence, Gender, Age

Citation: Eyo J.E., et al. (2014) Incidence and Prevalence of Parasites in Exotic Suis-Large White (Suidae) Slaughtered In a Tropical Urban Abattoir. International Journal of Parasitology Research, ISSN: 0975-3702 \& E-ISSN: 0975-9182, Volume 6, Issue 1, pp.-132-135.

Copyright: Copyright@2014 Eyo J.E., et al. This is an open-access article distributed under the terms of the Creative Commons Attribution License, which permits unrestricted use, distribution and reproduction in any medium, provided the original author and source are credited.

\section{Introduction}

Incidence and prevalence of parasites in pigs have been studied in; Plateau and Rivers States, Nigeria [1], Jos, Nigeria [2-5], Ibadan, Nigeria [6,7], Owerri, Nigeria [8], Ghana [9], Botswana [10], Zimbabwe [11], Kenya [12], south Georgia, USA [13], Nordic countries [14] and China $[15,16]$ among others. Suis generally are of religious, agricultural, pharmaceutical, industrial and medical uses for various products including insulin production, xenotransplantation, reservoir hosts to some human diseases (Balantidiasis, Cysticercosis and Trichinosis) and provision of meat, hair, blood, skin etc [4,5,17-19]. The importance of local pig breeds in the rural economy of Nigeria, which ranks them in number next to goats (excluding poultry) in the Western and Eastern States has been reported [17]. However, these local breeds have been gradually replaced by exotic breeds which receive relatively better care from farmers. In the Eastern part of Nigeria, inadequate information on the parasites associated with these exotic species as a template for piggery management, prevention of zoonoses and related general public health concerns exists. In this regard, some published works on both breeds in some parts of Nigeria have been recorded [1,6,7,17]. The present study was carried out to look at the prevalence and incidence of ecto- and endoparasites of slaughtered exotic pig breed (large white) in Ikpa Market abattoir, Nsukka.

\begin{abstract}
Materials and Methods
Study area

Ikpa Market abattoir is located in Nsukka metropolis $\left(6^{\circ} 51^{\prime \prime} 23^{\prime} \mathrm{N}\right.$; $7^{\circ} 23^{\prime \prime} 44^{\prime}$ E), Enugu State, in southeast geopolitical zone of Nigeria. It is a centre of palm oil trade blessed with the first Nigerian University, the University of Nigeria, commercial banks, hospitals, schools and network of transportation and communication systems. The town has an estimated population of 167,086 and is blessed with beautiful vegetation dotted with several soft green hills and a cool temperate-like weather. Pigs are supplied to the market from the University piggery as well as small scale farmers in the city. Pork is the meat of choice during traditional festivals.
\end{abstract}

\section{Sampling}

One hundred and eighty (180) pigs slaughtered at Nsukka abattoir between 1st July and 31st August 2012 were all examined for ectoparasites, endoparasites and blood parasites. Sex and age differences in parasite distribution were noted. The intestinal and skin parasites were collected from three groups according to their ages $[6,7]$. Animals in Group I were between the ages of 4 and 6 months, Group II 6 to 9 months and Group III over 9 months. Age and sex were assessed on the basis of dentition and teat, respectively. Prior to slaughtering, external parts of each pig (ear, tail, trunk and limbs) 
were examined for ectoparasites. Ectoparasites amassed were preserved in $2 \%$ formol-alcohol, examined under a stereo microscope and identified $[20,21]$. From each animal, thick and thin blood smears were made, fixed in methyl alcohol and stained in $10 \%$ Giemsa. Slides were observed at x100 magnification and blood parasites identified $[6,7]$. Fecal samples from all the pigs were examined for gastrointestinal helminths using filtration and sedimentation method. All recovered helminths were processed and identified [1,21-23]. Percentage incidence and prevalence were calculated using the following formulae: $\%$ Incidence $=x / n \times 100$ ( $x$ is the number of pigs infected per given age or sex and $n$ is the total number of pigs sampled within the particular age or sex); $\%$ Prevalence $=y /$ $\mathrm{n} x 100$ ( $\mathrm{y}$ is the number of pigs infected and $\mathrm{n}$ is the total number of pigs examined).

\section{Results}

Nine different parasites were recovered from the examined pigs. These included the ectoparasites: Sarcoptes suis and Haematopinus suis, and the endoparasites: Strongyloides ransomi, Eimeria sp and Ascaris suum. Haemoparasites recorded were Trypanosoma brucei, T. congolense, Babesia trautmanni and B. perroncitoi. The overall incidence rate of endoparasites was characteristically high. Strongyloides ransomi had the highest incidence rate $(142.60 \%)$ followed by Eimeria sp (135.00\%) whereas Ascaris suum had the least $(104.30 \%)$ [Table-1]. The age-wise incidence of endoparasites indicated that 4-6 months old pigs had highest incidence of S. ransomi (70.00\%), 7-9 months old pigs had highest incidence of Eimeria sp (50.0\%) and above 9 months old pigs had more A. suum $(37.50 \%)$ [Table-1]. The overall prevalence rate of endoparasites was characteristically high; Eimeria sp (51.70\%), S. ransomi (41.10\%) and A. suum (31.10\%) [Table-1]. The age-wise prevalence rate of endoparasites indicated that for pigs 4-6 months, S. ransomi (7.8\%) had the highest prevalence, $7-9$ as well as above 9 months pigs had highest prevalence of Eimeria sp (31.10\%) and (13.90\%), respectively [Table-1]. The overall incidence rate of ectoparasites was high for S. suis $(146.40 \%)$ and $H$. suis $(38.7 \%)$ [Table -1]. The age incidence rate of ectoparasites indicated that 4-6 months old pigs had $100 \% \mathrm{~S}$. suis incidence while $7-9$ months pigs had $33.90 \% S$. suis and above 9 months old pigs had $12.50 \% S$. suis [Table-1]. Comparatively, $H$. suis incidences were low for all age groups being $30 \%$ in $4-6 ; 3.60 \%$ in $7-9$ and $4.2 \%$ in above 9 months aged pigs. The overall age prevalence rate of ectoparasites was higher for $S$. suis $(35.50 \%)$ than $H$. suis $(6.60 \%)$ [Table- 1 ]. In all the age groups, $S$. suis was more prevalent than $H$. suis in all the age groups of pigs [Table-1].

The male pigs had higher incidence for $A$. suum (34.3\%), while females had higher incidence of S. ransomi (40.9\%) and Eimeria sp $(33.60 \%)$. All the studied endoparasites were more prevalent in the female pigs thus; S. ransomi (25.00\%), Eimeria sp (20.50\%) and $A$. suum $(15.50 \%)$ than in males pigs; S. ransomi (13.3\%), A. suum $(13.30 \%)$ and Eimeria sp (12.20\%) [Table-2]. Furthermore, the gender incidence of ectoparasites showed that the female pigs had more S. suis $(90.9 \%)$ than male pigs $(42.3 \%)$. On the other hand, male pigs had more of $H$. suis $(25.70 \%)$ than female pigs $(9.10 \%)$. Similar patterns were demonstrated in the gender prevalence of these ectoparasites [Table-2]. Out of 180 large white pigs examined for parasites, 143 were infected. In all S. ransomi had the highest prevalence $20.4 \%$ whereas $H$. suis $(3.40 \%)$ had the least infection [Table-2].

Table 1- Incidence and prevalence of endo- and ectoparasites by age of pigs slaughtered at Nsukka abattoir

\begin{tabular}{|c|c|c|c|c|c|c|c|c|c|c|c|c|c|c|c|c|}
\hline \multirow{3}{*}{$\begin{array}{l}\text { Age } \\
\text { Group } \\
\text { (Months) }\end{array}$} & \multirow{3}{*}{ No. } & \multicolumn{15}{|c|}{ Prevalence of Parasites by Age of Pigs } \\
\hline & & \multicolumn{3}{|c|}{ S. ransomi } & \multicolumn{3}{|c|}{ A. suum } & \multicolumn{3}{|c|}{ Eimeria sp. } & \multicolumn{3}{|c|}{ S. suis } & \multicolumn{3}{|c|}{ H. suis } \\
\hline & & A & Inc & Pre & B & Inc & Pre & C & Inc & Pre & D & Inc & Pre & $\mathrm{E}$ & Inc & Pre \\
\hline 04-Jun & 20 & 14 & 70 & 7.8 & 8 & 40 & 4.4 & 12 & 60 & 6.7 & 20 & 100 & 11.1 & 6 & 30 & 3.3 \\
\hline 07-Sep & 112 & 44 & 39.3 & 24.4 & 30 & 26.8 & 16.7 & 56 & 50 & 31.1 & 38 & 33.9 & 21.1 & 4 & 3.6 & 2.2 \\
\hline Above 9 & 48 & 16 & 33.3 & 8.9 & 18 & 37.5 & 10 & 12 & 25 & 13.9 & 6 & 12.5 & 3.3 & 2 & 4.2 & 1.1 \\
\hline Total & 180 & 74 & 142.6 & 41.1 & 56 & 104.3 & 31.1 & 40 & 135 & 51.7 & 64 & 146.4 & 35.5 & 12 & 38.7 & 6.6 \\
\hline \multicolumn{17}{|c|}{ Key: $A-E=$ number of pigs infected per parasite for a given age; $\operatorname{lnc}=\%$ incidence } \\
\hline
\end{tabular}

Table 2- Incidence and prevalence of endo- and ectoparasites in relation to sex of pigs slaughtered in Nsukka abattoir between July and August, 2012

\begin{tabular}{|c|c|c|c|c|c|c|c|c|c|}
\hline \multirow{3}{*}{ Parasites } & \multicolumn{6}{|c|}{ Sex } & \multirow{2}{*}{\multicolumn{3}{|c|}{ Total $(n=180)$}} \\
\hline & \multicolumn{3}{|c|}{ Male $(n=70)$} & \multicolumn{3}{|c|}{ Female $(n=110)$} & & & \\
\hline & A & Inc & Pre & B & Inc & Pre & C & Inc & Pre \\
\hline \multicolumn{10}{|l|}{ Endoparasites } \\
\hline Strongyloides ransomi & 24 & 34.3 & 13.33 & 45 & 40.9 & 25 & 69 & 75.2 & 38.33 \\
\hline Ascaris suum & 24 & 34.3 & 13.33 & 28 & 25.5 & 15.56 & 52 & 59.8 & 28.89 \\
\hline Eimeria sp. & 22 & 31.4 & 12.22 & 37 & 33.6 & 20.56 & 59 & 65 & 32.78 \\
\hline \multicolumn{10}{|l|}{ Ectoparasites } \\
\hline Sarcoptes suis & 52 & 42.3 & 28.9 & 100 & 90.9 & 55.6 & 152 & 133.2 & 84.5 \\
\hline Haematopinus suis & 18 & 25.7 & 10 & 10 & 9.1 & 5.6 & 28 & 34.8 & 15.6 \\
\hline
\end{tabular}

The age incidence of haemoparasites indicated that $B$. trautmanni were more in the above 9 months pigs $(45.83 \%)$, while $B$. perroncitoi were more in the $7-9$ months pigs $(36.61 \%)$. Furthermore, the age incidence of haemoparasites equally indicated that $T$. brucei $(12.50 \%)$ was more in above 9 months pigs, while $T$. congolense $(20.00 \%)$ was high in 4-6 months old pigs. T. congolense was more prevalent in age group $7-9$ months pigs $(7.80 \%)$ than in above 9 months pigs (3.30\%) and 4-6 months pigs (2.20\%) [Table-3]. 
Table 3- Incidence and prevalence of haemoparasites in relation to age of pigs slaughtered in Nsukka abattoir between July and August, 2012.

\begin{tabular}{|c|c|c|c|c|c|c|c|c|c|c|c|c|}
\hline \multirow[t]{2}{*}{ Haemo-parasites } & \multicolumn{6}{|c|}{$\begin{array}{c}\text { Age } \\
7-9 \text { months } \\
\text { (n=112) }\end{array}$} & \multicolumn{3}{|c|}{$\begin{array}{l}\text { Above } 9 \text { months } \\
\qquad(n=48)\end{array}$} & \multicolumn{3}{|c|}{$\begin{array}{l}\text { Total } \\
(n=180)\end{array}$} \\
\hline & A & Inc & Pre & B & Inc & Pre & C & Inc & Pre & D & Inc & Pre \\
\hline Trypanosoma brucei & 2 & 10 & 1.1 & 10 & 8.9 & 5.6 & 6 & 12.5 & 3.3 & 18 & 31.4 & 10 \\
\hline Trypanosoma congolense & 4 & 20 & 2.2 & 14 & 12.5 & 7.8 & 6 & 12.5 & 3.3 & 24 & 45 & 13.3 \\
\hline Babesia trautmanni & 8 & 40 & 4.44 & 47 & 41.96 & 26.11 & 22 & 45.83 & 12.22 & 77 & 127.79 & 42.77 \\
\hline Babesia perroncitoi & 6 & 30 & 3.33 & 41 & 36.61 & 22.78 & 14 & 29.17 & 7.78 & 61 & 95.78 & 33.89 \\
\hline
\end{tabular}

Table 4- Incidence and prevalence of haemoparasites in relation to sex of pigs slaughtered in Nsukka abattoir between July and August, 2012.

\begin{tabular}{|c|c|c|c|c|c|c|c|c|c|}
\hline \multirow{3}{*}{ Haemo-parasites } & \multicolumn{6}{|c|}{ Sex } & \multirow{2}{*}{\multicolumn{3}{|c|}{ Total $(n=180)$}} \\
\hline & \multicolumn{3}{|c|}{ Male $(n=70)$} & \multicolumn{3}{|c|}{ Female $(n=110)$} & & & \\
\hline & A & Inc & Pre & B & Inc & Pre & C & Inc & Pre \\
\hline Trypanosoma brucei & 10 & 14.3 & 5.6 & 8 & 7.3 & 4.4 & 18 & 21.6 & 10 \\
\hline Trypanosoma congolense & 10 & 14.3 & 5.6 & 14 & 12.7 & 7.8 & 24 & 27 & 13.4 \\
\hline Babesia trautmanni & 23 & 32.86 & 12.78 & 40 & 36.36 & 22.22 & 63 & 69.22 & 35 \\
\hline Babesia perroncitoi & 27 & 38.57 & 15 & 48 & 43.64 & 26.67 & 75 & 82.21 & 41.67 \\
\hline Key: $A-C=$ number of pigs & perp & ra give & $c=\%$ ir & & & & & & \\
\hline
\end{tabular}

The sex associated incidence of haemoparasites indicated that $T$. brucei were more in males $(14.30 \%)$ than in females $(7.3 \%)$, while $T$. congolense were equally more in males $(14.30 \%)$ than in females $(12.70 \%)$. Trypanosoma brucei was more prevalent in males $(5.60 \%)$ than in females $(4.40 \%)$ [Table-4]. On the other hand, the prevalence of $T$. congolense was more in females $(7.80 \%)$ than in males $(5.60 \%)$. Incidences of $B$. trautmanni and $B$. perroncitoi haemoparasitic infection were more in females $(36.36 \%, 43.64 \%)$ than in males $(32.86 \%, 38.57 \%)$. Similar patterns were demonstrated in the sex associated prevalence of these haemoparasites [Table-4].

\section{Discussion}

Although Haematopinus suis was recovered, the major haemoparasite that it transmits-Eperythrozoon sp was not found in the blood of the pigs.

The infection would spread if there is introduction of reservoir hosts by whatever means in Nsukka area. Age group 7-9 months was mostly affected by the various parasites except in the infection of $H$. suis which had most infection among those between 4-6 months. High prevalence of infection in all except in $H$. suis indicates poor environmental conditions and treatments. Most commercial and subsistence farms pay inadequate attention to hygiene. Obvious ulcerated skins should have been eliminated by applying drugs of choice and general treatments of the wounds to avoid probable secondary infection of bacteria, mycoplasma and viruses [24,25]. Ectoparasites such as $H$. suis and $S$. suis among other things cause irritation and itching, making the animal restless and not feeding properly thus leading to weight loss $[20,26]$. Also, T. brucei and $T$. congolense which have been reported in pigs from other parts of Nigeria and African countries were found in Nsukka pigs because palpalis group of Glossina i.e. Glossina tachinoides and Glossina palpalis, the usual vectors are found in Nsukka area [27]. Furthermore, earlier study from Nigeria had reported the prevalence of both $B$. trautmanni and B. perroncitoi in pigs [5]. The high prevalence of Babesia haemoparasites in this study is in agreement with Kahn [28] who reported that Babesia trautmanni has been recorded as causing severe disease in pigs in Europe and Africa. He further reported that another species Babesia perroncitoi is of similar pathogenicity but apparently has a limited distribution in areas mentioned above. The points of attachments of the ectoparasites were ulcerated; usually these points serve as entry points for bacteria and viruses. Also it affects the marketability of pigs and its acceptance as a source of protein. Eimeria sp is an intracellular coccidian parasite which causes coccidiosis i.e. harmful damage to the epithelial cells of pigs' intestine $[29,30]$. Parasites have been associated with pigs in many parts of Nigeria and the world at large. Some of the studies showed similarities in the types of parasites recovered $[1,7,25,31]$, high prevalence to infection $[6,14,32]$ and intensity $[10,11,16,33]$. Generally in Nigerian piggery management systems, pigs are often semi-intensively managed and this dangerously exposes them to parasitic infections. Older pigs (above 9 months) were less infected than younger ones (4-7 months). This could arise from acquisition of immunity due pre-exposure to these parasites and molecular associations unlike younger ones during the course of their lives. Gastrointestinal parasites are acquired through tropic relationships as a result of poor environmental conditions [34].

For instance, $A$. suum is the most common parasite in modern piggery operations with approximately $70-80 \%$ of pigs infected. A single female can lay up to one million eggs per day. These eggs can remain viable in the environment for up to thirty years. This parasite is also the largest one measuring in length more than eight inches during the adult form. The adult inhabits the small intestine where it swims against the flow of the intestinal contents. They sometimes migrate into the pigs' stomach where they cause the host to vomit both the feed and worms. In the host intestine, these worms compete for nutrients which leads to diminished growth, disease and economic losses $[25,35]$. Due to lack of circular muscles in nematodes, conventional contraction and relaxation of muscles is not achieved so resultant thrusting movements of these worms cause damages to the internal organs. This causes white scar lesions which predispose the hosts to infectious agents such as mycoplasmal bacterial and viral infections.

\section{Conclusion}

Nine different parasites were recorded from the examined pigs. These were ectoparasites: Sarcoptes suis and Haematopinus suis, and the endoparasites: Strongyloides ransomi, Eimeria sp and Ascaris suum. Haemoparasites were Trypanosoma brucei, T. congolense, Babesia trautmanni and B. perroncitoi. All the parasites are of public health importance. Pig farmers are to frequently deworm 
their pigs and maintain high management practices like raising pig in insect free/screen stall, regular veterinary screening of pigs for parasites and treatment of infected pigs. Furthermore, since this is of a public health concern, meat inspectors should ensure that infected pigs are not sold to consumers.

\section{Author's Contribution}

JEE conceived the study and developed the study protocols. PCE, $\mathrm{BCO}, \mathrm{CIA}$ and $\mathrm{NI}$ supported field operations and data collection. FNE, CDN and GCO performed literature search and data analysis. JEE and USO wrote the drafted the manuscript. The final manuscript has been read and approved for publication by all the authors.

\section{Acknowledgements}

We are thankful to the Department of Zoology and Environmental Biology, University of Nigeria for the provision of laboratory space and facilities for this study. We are also thankful to Mr. Christian Chukwuka who read and criticized the initial manuscript and Ms. Nkechi Onah for word processing the draft manuscript. This study was financed by the authors. We acknowledge that there is no conflict of interest among authors, individuals, organizations and the general public vis-à-vis the publication of this research report.

\section{Conflicts of Interest: None declared.}

\section{References}

[1] Salifu D.A., Manga T.B. and Onyali I.O. (1990) Rev. Elev. Med. Vet. Pays Trop., 43(2), 193-196.

[2] Fabiyi J.P. (1979) J. Helminthol., 53, 69-71.

[3] Ajayi J.A., Arabs W.L. and Adeleye G.A. (1988) Bull. Anim. Health Prod. Afr., 36, 47-54.

[4] Weka R.P. and Ikeh I.E. (2009) J. Anim. Vet. Adv., 8(5), 883-887.

[5] Pam V.A., Daniel L.N., Bata S.I., Udokaninyene A.D., Hassan A.A., Kemza S.Y., Igeh C.P. and Ogbu K.I. (2013) J. Vet. Adv., $3(2), 79-86$.

[6] Okon D. (1976) Trop. Anim. Health Prod., 8, 96.

[7] Dipeolu O.O., Majaro O.M., Akinboade O.A. and Nwufor K.J. (1982) Vet. Parasitol., 101, 87-90.

[8] Opara M.N., Ibekwe N., Azubuike J.C. and Okoli C.G. (2006) Inter. J. Nat. Appl. Sci., 2(1), 72-77.

[9] Permin A., Yelifari L., Bloch P., Steenhard N., Hansen N.P. and Nansen P. (1999) Vet. Parasitol., 87(1), 63-67.

[10]Nsoso S.J., Mosala K.P., Ndebele R.T. and Ramabu S.S. (2000) Onderstepoort J. Vet. Res., 67, 217-220.

[11]Marufu M.C., Chanayiwa P., Chimonyo M. and Bhebhe E. (2008) Afr. J. Agric. Res., 3, 91-95.

[12]Nganga C.J., Karanja D.N. and Mutune M.N. (2008) Trop. Anim. Health Prod., 40(5), 331-334.

[13]Andrews J.S., Stewart T.B., Richardson G.V. and McCormick W.C. (1970) J. Parasitol., 56, 1210-1217.

[14]Roepstorff A., Nilsson O., Oksanen A., Gjerde B., Richter S.H., Örtenberg E., Christensson D., Martinsson K.B., Bartlett P.C., Nansen P., Eriksen L., Helle O., Nikander S. and Larsen K. (1998) Vet. Parasitol., 76, 305-319.

[15]Boes J., Willingham A.L., Fuhui S., Xuguang H., Eriksen
L., Nansen P. and Stewart T.B. (2000) J. Helminthol., 74(1), 4552.

[16]Weng Y.B., Hub Y.J., Lib Y., Lib B.S., Lina R.Q., Xiea D.H., Gasserc R.B. and Zhua X.Q. (2004) Prev. Vet. Med., 10, 10-16.

[17]FAO (1965) Agricultural Development in Nigeria 1964-1980, FAO Report, Rome.

[18]Adetokunbo O.L. and Gilles H.M. (2003) A Short Text Book of Public Health Medicine for the Tropics, 4th ed., International Students Edition, Oxford University Press Incorporated, Oxford.

[19]Mader S.S. (2006) Human Biology, Oxford University Press Inc, New York.

[20]Dwight G.B. (1975) External Parasites, Diseases of Swine, 4th ed., The lowa State University Press, lowa.

[21]Corwin R.M. (1997) Swine Health Prod., 5(2), 67-70.

[22]Esrony K., Kambarage D.M., Mutambo M.A., Muhairwa A.P. and Kusiluka J.M. (1997) Prev. Vet. Med., 32, 41-46.

[23] Ivoke N. (2006) Parasitological Techniques, Manual of Laboratory Techniques in Biology, University of Nigeria Press Limited, Nsukka, Nigeria.

[24]Dunne W.H. and Leman D.A. (1975) Diseases of Swine, 4th ed., The lowa State University Press, lowa.

[25]Olson M.E. and Guselle N. (2000) Adv. Pork Prod., 11, 153162.

[26]Strueh K. (1994) A Comprehensive Review of Internal and External Parasites in Swine, Hoechst \& Roussel, New York.

[27]Madubunyi L.C. (1987) Ann. Trop. Med. Parasitol., 81(3), 319329.

[28]Kahn C.M. (2006) The Merck Veterinary Manual, 9th ed., Merck and Company Incorporated, Whitehouse Station, New Jersey, USA.

[29]Dunlap J.S. (1975) Protozoa, Diseases of Swine, 4th ed., The lowa State University Press, lowa.

[30]Jordan E.L. and Verma P.S. (2006) Invertebrate Zoology, Chand and Company, New Delhi, India.

[31]Wagner B. and Polly L. (1997) Vet. Parasitol., 73, 309-313.

[32]Roepstorff A., Bjørn H., Nansen P., Barnes E.H. and Christensen C.M. (1996) Inter. J. Parasitol., 26, 399-408.

[33]Frontera E., Alcaide M., Boes J., Hernández S., DomínguezAlpízar J.L. and Reina D. (2007) Vet. Parasitol., 146, 50-57.

[34]Helwigh A.B., Christensen C.M., Roepstorff A. and Nansen P. (1999). Exp. Parasitol., 8, 51-55.

[35]Georgi J.R. and Georgi M.E. (1990) Parasitology for Veterinarians, 5th ed., WB Saunders, Philadelphia. 